\title{
Towards a pluralistic and experiential teaching of economics for the Agenda 2030. The SDSN France textbook.
}

\author{
Thomas Lagoarde-Segot ${ }^{1}$ \\ Laurence Le Poder ${ }^{2}$
}

\begin{abstract}
The goals of the Agenda 2030 require a significant effort to educate and train new generations on sustainability issues. This article presents an initiative in favor of the evolution of the contents and the pedagogy of economics at the University level. We present the new "Ecological Money and Finance" textbook developed by SDSN France. We detail the assumptions, contents and learning objectives proposed in this new textbook. Then, we describe how it can be used in the framework of an experiential pedagogy of economics, taking as a case study the fundamental economics course of the Grande Ecole program at KEDGE BS.
\end{abstract}

Keywords: Economics education, Sustainability JEL Codes: G00

\footnotetext{
1 Thomas Lagoarde-Segot is with KEDGE BS and director of the Sustainable Finance group of SDSN France. Contact: thomas.lagoardesegot@kedgebs.com.

${ }^{2}$ Laurence Lepoder is with KEDGE BS and associate professor of economic and crisis management. She is a member of PocFiN and SDSN France.Contact: Laurence.lepoder@kedgebs.com
} 


\section{Introduction}

As early as 1890, the economist Alfred Marshall wrote: "economic conditions are continually changing, and each generation is led to deal with its economic problems independently" (Marshall, 1890, p.5). Our generation is, in turn, confronted with particularly pressing problems: financial crises, the uncertain effects of technological change, widening income and wealth inequalities, rising public and private debts, geopolitical tensions, climate change, degradation of natural systems...

The Great Industrial Acceleration has now been identified as the root cause of Earth system disruption (Steffen et.al, 2015). This disruption is compromising the resilience of our global supply system, as well as life on Earth (Nyströmet al.,2019; Galaz et al., 2019;Dron, 2015; Svartzmanet al., 2019; IBPES, 2019). The rate of species extinction is now 100 times higher than the average observed over the past 10 million years. Nearly 1 million species are threatened with extinction. Compliance with the Paris Agreements which commit to keeping global warming well below the $2^{\circ}$ mark by 2100 - is therefore a civilizational issue.

The current context hence calls into question our mental and conceptual models. As shown in Figure 1, a simple linear regression between global GDP and kilotons of $\mathrm{CO} 2$ emissions displays a correlation coefficient of 0.966. Similarly, a linear regression between global market capitalization and CO2 emissions shows a correlation coefficient of 0.960 . The accumulation of monetary wealth thus masks the unaccounted for destruction of ecosystem services. As shown in Figure 2, the new bio-geophysical and social context threatens to render obsolete the teachings provided in universities and business schools (Hall, 2017).

Figure 1: Atmospheric CO2 emissions and economic and financial development, 1960-2019 (pvalue 0.000 )
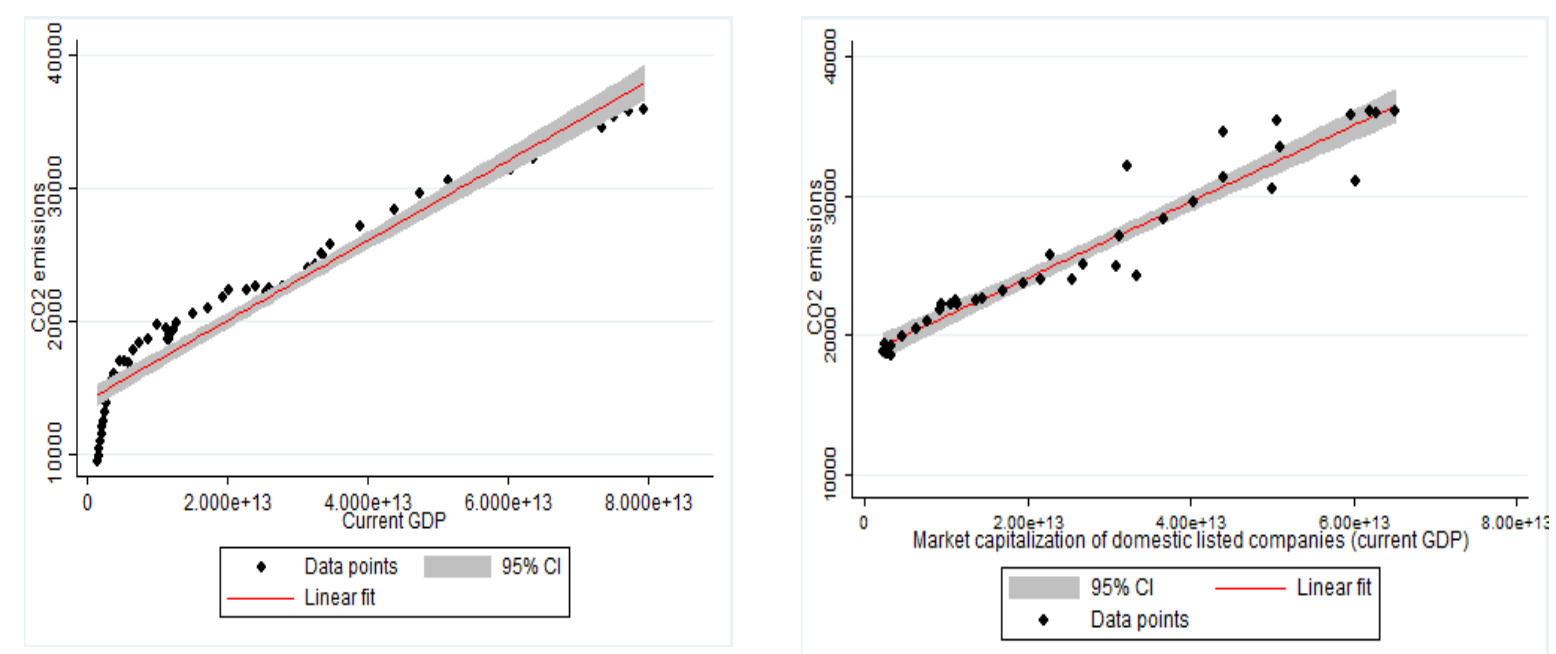

Source: Authors' calculation based on World Bank data (data.worldbank.org).

To achieve SDGs, the education and training of new generations is a fundamental issue. In this article, we present an initiative to renew economic education at the university level. Indeed, economic education aims to prepare students simultaneously for professional, political and social life. Economics provides access to analytical tools and concepts that allow not only to understand the world, but also to act in an informed way. In the best of cases, economics allows us to understand how we can organize society to allow the "realization of human potential" (A. Sen): that is to say, to grant everyone the possibility of 
leading a life worth living. Economics therefore has, alongside the other social sciences, an important role to play in education to sustainable development.

Figure 2 Are economic theories obsolete?

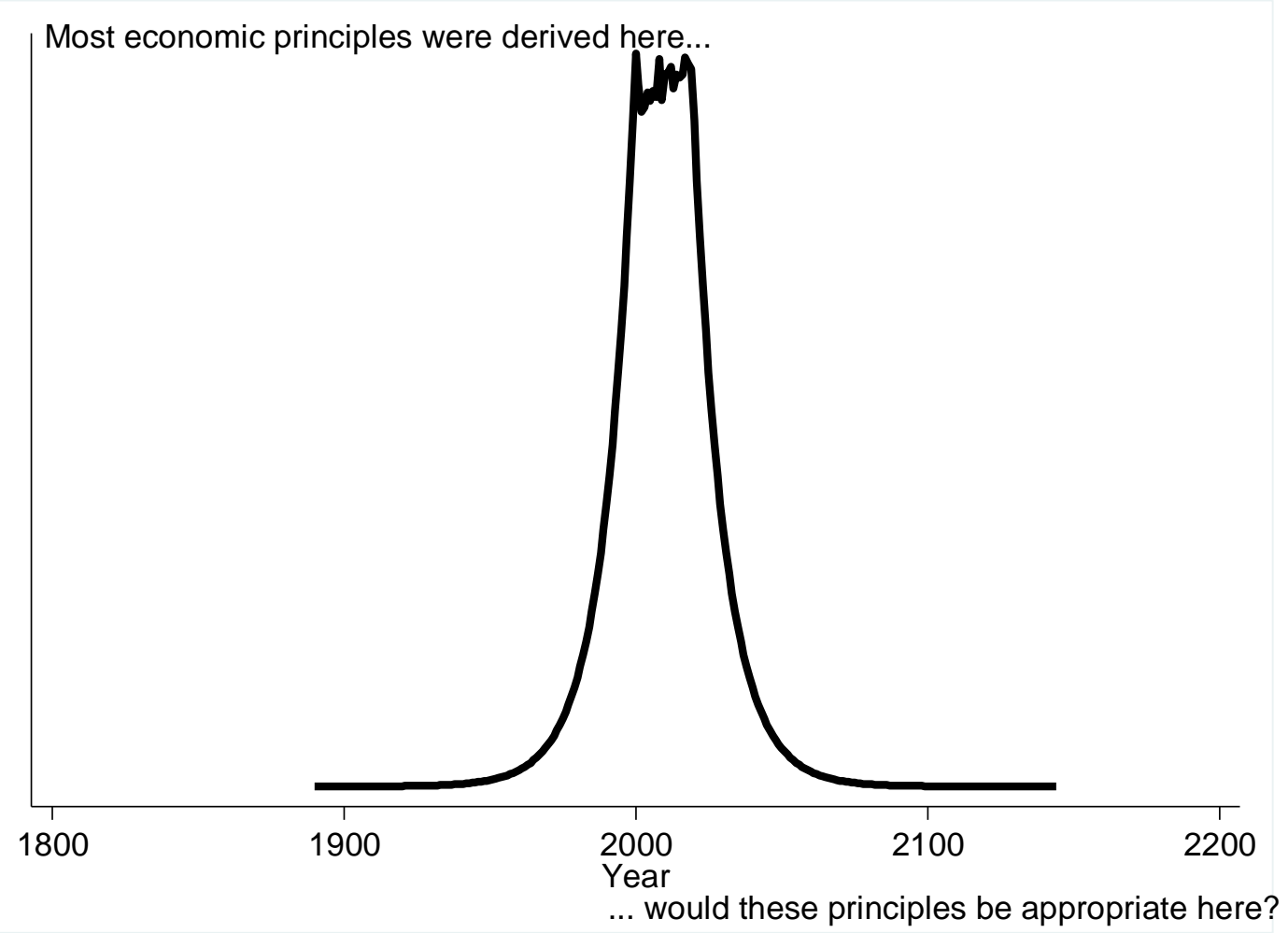

Source: adapted from Hall (2017). This diagram is a heuristic representation of the relationship between the development of economic and financial theories and access to resources. It questions the relevance of economic theories developed in a world of abundant energy; in a new world characterized by the collapse of vital resources (biodiversity, energy, air, water...)

Nevertheless, most of the economic, managerial and financial theories taught were conceived in the 19th and 20th centuries, on the assumption of a world without limits. By reducing the whole (society) to the sum of its parts (the individual), these theories tend to underestimate the complex interactions between the parts that generate, constrain, or accelerate the dynamics of the whole (the social and bio-geophysical system), and exert in return a feedback effect on the behavior of individuals (Lagoarde-Segot and Martine, 2021). Economics textbooks are essentially based on a neoclassical and neo-Keynesian vision based on reductionism and the theory of market efficiency. Within this framework, endemic financial crises, rising income inequalities, and, more critically, a disruption of the scale of the Anthropocene are difficult to envisage.

Therefore, it is perhaps not surprising that the new generations of students no longer hesitate to question the economics teachings received at the University. In recent years, several student movements have criticized their teachers for not taking sufficiently into account economic realities and for presenting a monistic vision of economics ${ }^{3}$. At the forefront of their demands are pluralism, the consideration of the limits of "mathematized" economic models, more courses on the history of economic thought, more

\footnotetext{
${ }^{3}$ For example, the International Student Initiative for Pluralism in Economics (http://www.isipe.net/), or, in the French context the Manifeste pour un Réveil Ecologique (Manifesto for an Ecological Awakening) (https://pourun-reveil-ecologique.org/fr/).
} 
links with the other social sciences, and a better consideration of the dramatic ecological challenges of the 21 st century.

In response to this issue, a group of economists who are members of the PoCfiN ${ }^{4}$ network have launched in 2019, with the support of the SDSN France network, a new textbook project entitled Ecological Money and Finance (forthcoming, 2022). This textbook is intended for undergraduate and graduate students, as well as continuing education students, both specialists and non-specialists. Its ambition is to contribute to equipping new generations with the skills and analytical tools to enable them to solve the new economic and social problems arising with the Anthropocene. The particularity of this manual is to integrate the monetary and financial side in an analysis of economies, with a strong focus on Agenda 2030. It also introduces three innovations in the teaching of economics at the university level.

First, this textbook is based on a robust ontological and epistemological framework connected to the Earth Sciences. It presents the economic and financial world as a sub-system of the social and biogeophysical system. This (re)definition of the object of study (the economy) thus leads students to take a fresh look at economic controversies. Given the challenges posed by the Agenda 2030, this redefinition is essential since ontological choices determine the language, methods, and acceptable responses in the sciences (Lawson, 2018).

Second, the textbook takes an axiological approach, and acknowledges the dilemmas posed by the SDGs. Extending the pioneering work of Reardon et.al (2018), it attempts to tackle those issues by analyzing the economy and the financial system from four explicit principles: realism, pluralism, diversity, and justice. This perspective thus allows professors to distance themselves from the instrumentalism and reductionism characteristic of orthodox economic approaches, and to adopt a holistic and interdisciplinary perspective in their teaching - without, however, abandoning the specific contributions of economic analysis (notably modeling) to SDGs. For each topic covered, the textbook mobilizes several relevant economic theories, in line with a clear objective: making economic education a lever for acting, with awareness, on the world.

Third, the textbook introduces an explicit learning theory to achieve its learning objectives. The proposed contents are designed to be used within the framework of experiential learning, as developed initially by Dewey (1938), and currently used in many works in didactics (Lambert, 2019). The pedagogical proposal of this textbook is to teach economics on the basis of a flipped pedagogy: class time is used to deepen the understanding of economic theories, to co-construct knowledge by developing learning experiences (case studies, role-playing games, simulation games...), in all cases using economic, social and ecological data that students can search for on the internet.

The rest of this article is structured as follows. The second section highlights the need to redesign economics education to build a resilient society by emphasizing the performativity of economics. The third section presents the four principles of the textbook: realism, pluralism, diversity, justice, describes its content, and presents the learning theory. The fourth section illustrates how this textbook can be use, by the fundamental economics course at KEDGE BS, which is taken annually by about 1000 students, as an example. The fifth section gathers our conclusions, and attempts to draw perspectives for economic education in the 21 st century.

\footnotetext{
${ }^{4}$ PoCfiN (post-crisis finance research network) is an international network created by KEDGE BS and the College of Global Studies of the Fondation Maison des Sciences de l'Homme (FMSH), and integrated into SDSN France.
} 


\section{The performativity of economic education}

In a 1993 article in the Journal of Economic Perspectives, Robert Frank, Thomas Gilovich and Dennis Regan assigned students from different majors in pairs. Each pair consisted of a "planner" student and a "receiver" student. Each "planner" was given a sum of ten dollars, and then had to propose to the "receiver" a distribution of that sum. The "receiver" was then faced with the following choice: he could either accept the distribution proposed by the "planner" (in which case both participants would pocket their respective shares); or he could refuse this distribution (in which case the ten dollars would be removed from the game). The experiment showed that most of the "planners" proposed an egalitarian distribution (50\%-50\%), except for the economics students, who proposed, on average, more unequal distributions. This may not come as a surprise given that neoclassical microeconomics would predict that the "receiver" will always prefer to pocket $\$ 0.01$ than to pocket nothing at all: a distribution that would allocate $\$ 9.99$ to the "planner" and $\$ 0.01$ to the "receiver" is Pareto-optimal.

This experience illustrates the performativity of economic science: language and economic concepts, by impregnating the consciousness of individuals, contribute to structuring the reality they were supposed to describe. The performativity of economics distinguishes it from the so-called "hard" sciences. Indeed, in the hard sciences, the behavior of the studied phenomena (for example, the trajectory of a meteorite) is in no way influenced by the tested theory (for example, the theory of universal gravitation): whether the theory is valid or not, the meteorite will follow the same trajectory. This separation between the observer and the observed does not hold, however, in the social sciences. Indeed, our social behaviors are formed by shared conceptual frameworks, and these are precisely the end product of social sciences. As soon as a theory gains sufficient credibility, it gradually permeates the mindsets and behaviors of agents and influences the object it sought to describe.

The responsibility of neoclassical financial theory in triggering financial crises and in the deterioration of organizational management is often given as an example. In its purest version, this theory reduces economic analysis to the behavior of a selfish, rational and omniscient individual who has direct access to all available information and who makes investment decisions at each moment via a mathematical "utility function". It follows that, in the absence of "rigidities", the financial markets are capable of discovering the true economic model of the world, and of revealing it to all actors in the form of a vector of equilibrium prices. The main implication of this theory is that it is optimal to entrust financial markets (and their control indicators) with the command of the economy. As Figure 1 shows, this theory is based on a cocktail of "scientism" (the imitation of Newtonian physical science procedures in the field of economics $^{5}$ ) and a liberal ideology (which posits "freedom as the ultimate goal, and the individual as the ultimate entity of society" (Friedman, 2002)). Its hegemony in economics departments and business schools has thus deteriorated the quality of management practices (by justifying cynical and dangerous behavior), and has led to a rise in systemic risk (Ghosh, 2005).

\footnotetext{
5 The "pretense to knowledge" was criticized, among others, by Friedrich von Hayek in his Nobel Prize acceptance speech in 1989: "It seems to me that the failure of economists to guide policy properly is connected with their propensity to imitate the procedures of physical science - an attempt, which in our field can lead to serious mistakes. This is an approach that can be described as 'scientistic' (...) it relies on the mechanical and uncritical transposition of habits of thought to areas very different from those in which these habits of thought were formed.
} 


\section{Figure 1 How bad theories destroy good practices}

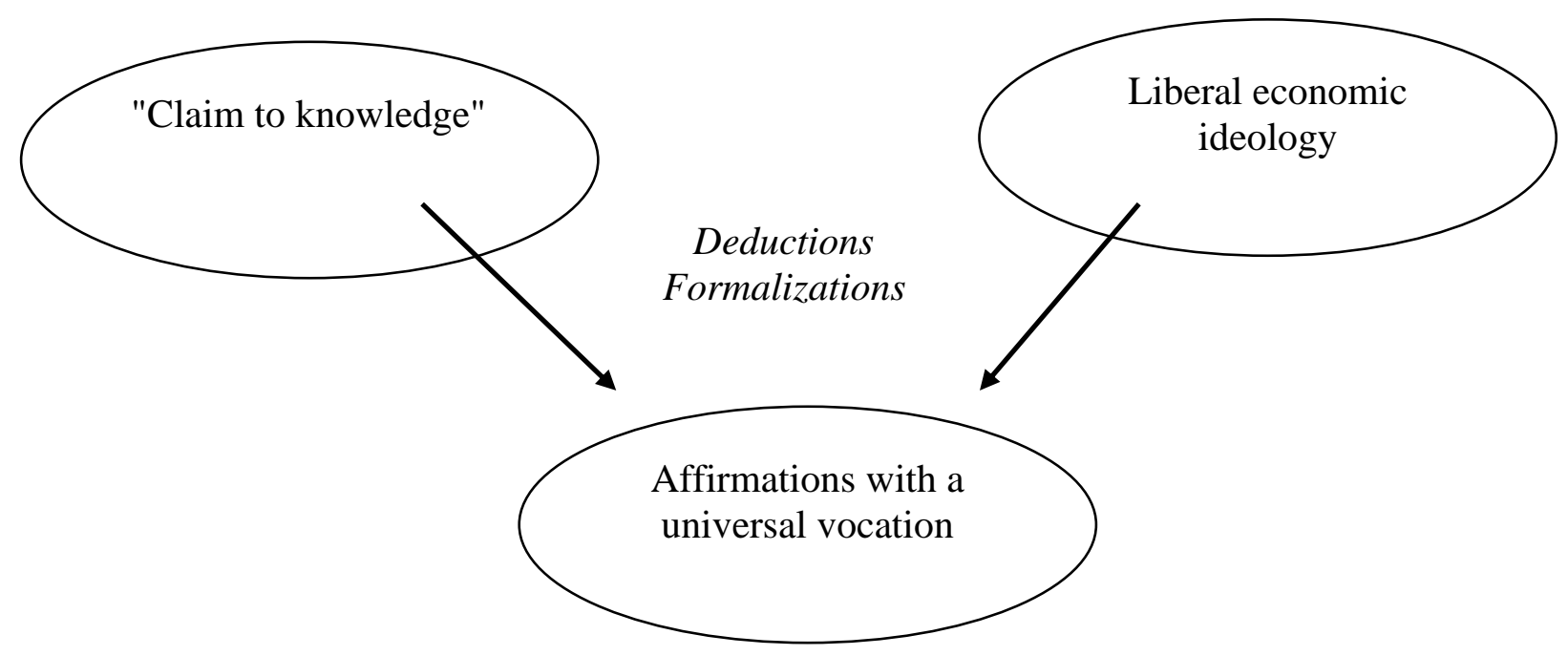

Source: Goshal (2005)

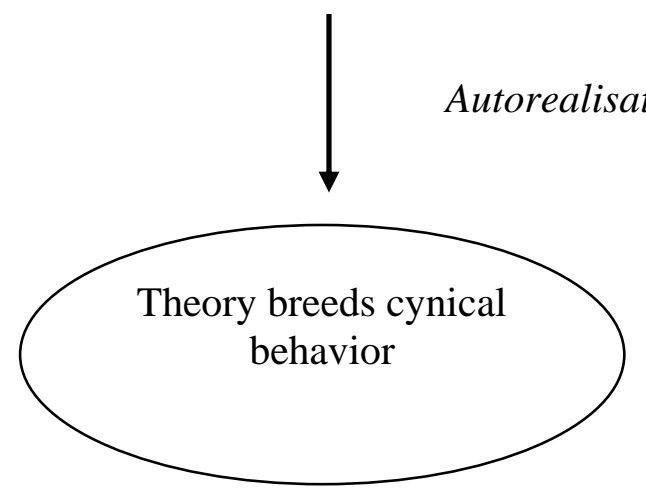

The performativity of economic science makes economic education an ambivalent object in the perspective of the Agenda 2030. Economic education may be an obstacle to achieving the SDGs, but it can also be a powerful lever. In 2018, fifteen economists members of the PoCfiN Alliance (post-crisis finance network) were thus mandated by the SDSN France (in connection with the UN's SDG Academy), to write a new textbook to align economics education with sustainability objectives. This textbook, which is currently being written and whose final publication is planned for 2022, is divided into three parts of approximately seven chapters, as described in Table 1.

The first part of the textbook analyzes the market, the firm and governance from the perspective of the Agenda 2030. The second part analyzes the details of the functioning and evolution of the monetary and financial system, also under the prism of the SDGs. Finally, the third part mobilizes the field of critical management studies to understand, through contextualized case studies, the origins of the failures of the conventional financial system, and the solutions provided by the actors committed to sustainability. Each chapter contains learning objectives, concrete examples, case studies and internet resources, as well as a database of multiple-choice questions inserted in a dedicated module of the Sustainability Literacy Test ${ }^{6}$. The textbook will also be supported by videos and open-access teaching narratives developed in partnership with the Sustainable Development Goal Academy.

${ }^{6}$ https://www.sulitest.org/en/vision-mission.html?newWorkingLanguage=en 


\section{Table 1Outline of the SDSN France manual}

\begin{tabular}{|c|c|c|}
\hline $\begin{array}{l}\text { Part } 1 \text { Markets, Firms and } \\
\text { Governance }\end{array}$ & $\begin{array}{l}\text { Part } 2 \text { Monetary economy of } \\
\text { production }\end{array}$ & Part 3 Financial studies \\
\hline $\begin{array}{l}\text { 1. Economic theories and } \\
\text { reality }\end{array}$ & $\begin{array}{l}\text { 8. Modern money and the } \\
\text { payment system }\end{array}$ & $\begin{array}{l}\text { 15. Finance from the perspective of } \\
\text { social sciences }\end{array}$ \\
\hline $\begin{array}{l}\text { 2. Economic systems and } \\
\text { diversity }\end{array}$ & $\begin{array}{l}\text { 9. Macroeconomics of the } \\
\text { money circuit }\end{array}$ & 16. Pricing and secondary markets \\
\hline $\begin{array}{l}\text { 3. Markets, competition and } \\
\text { price formation }\end{array}$ & $\begin{array}{l}\text { 10. Introduction to economic } \\
\text { modeling }\end{array}$ & $\begin{array}{l}\text { 17. Financial asset management } \\
\text { and sustainability }\end{array}$ \\
\hline $\begin{array}{l}\text { 4. Heterodox theories of the } \\
\text { firm }\end{array}$ & $\begin{array}{l}\text { 11. Interest rates and } \\
\text { monetary policy }\end{array}$ & $\begin{array}{l}\text { 18. Finance, subjectivity, } \\
\text { spirituality }\end{array}$ \\
\hline $\begin{array}{l}\text { 5. Corporate governance and } \\
\text { democracy }\end{array}$ & $\begin{array}{l}\text { 12. Trade and financial } \\
\text { imbalances }\end{array}$ & 19. Islamic finance \\
\hline 6. The financialized company & $\begin{array}{l}\text { 13. Understanding exchange } \\
\text { rates }\end{array}$ & 20. Financial and social inclusion \\
\hline $\begin{array}{l}\text { 7. Towards a new ecological } \\
\text { accounting }\end{array}$ & $\begin{array}{l}\text { 14. International financial } \\
\text { architecture }\end{array}$ & $\begin{array}{l}\text { 21. Participatory finance and } \\
\text { crowdlending }\end{array}$ \\
\hline
\end{tabular}

Note: This table shows the projected outline of the SDSN France Economics and Finance textbook. The arrangement of the topics may change between now and the publication of the textbook.

\section{The key principles of the manual}

In order to train future generations toachieve the 2030 Agenda, the textbook contributes to the redesign of economics and finance education at the university level based on four explicit principles: realism, economic diversity, pluralism and justice. To achieve long-term learning objectives (comprising knowledge, skills and know-how), it mobilizes an explicit learning theory: experiential learning and the main pedagogical practices related to it.

\subsection{Realism}

As with any other discipline, economic analysis must be based on a good definition of its object of study ${ }^{7}$. It is now established that the Earth behaves as an integrated Earth-System, in which the oceans, the atmosphere and the land as well as all living organisms are connected (IGBP, 2004). Rigorously defining the economy, taking into account the relationship with society and the Earth System, is therefore an indispensable prerequisite for renewing the study of economics in the context of the Anthropocene. As shown in Figure 2, the socio-economic sphere, the object of economic analysis, can be represented as a subsystem of the biosphere.

The function of the socio-economic sphere is to provide human beings with an energy flow that ensures the survival and reproduction of the species. From the Neolithic Revolution onwards, a material surplus appears, which circulates in the form of goods, services, and human labor, in response to social wants. This material surplus is extracted, distributed and used according to criteria that vary according to time and place.

On the basis of these observations, the textbook rejects the neoclassical definition of economics as "the science of the allocation of scarce resources" preferring instead the classical definition of economics as "the science of the social provisioning process". Social provisioning can be defined as "an instituted

\footnotetext{
7 "With any phenomenon of interest, understanding its nature or essential properties allows us to relate to, and interact with, in more knowledgeable and competent ways than would otherwise be the case" (Lawson, 2019, p.3).
} 
process of interaction between man and his environment, resulting in a continuous supply of material means to satisfy needs" (Polanyi, 1983, p.145 ). Studying the economy in the 21st century consists in understanding the mechanisms by which a society identifies, produces and distributes the flow of goods and services required by the needs of its members ${ }^{8}$ in a given institutional and cultural context, in interaction with the Earth system.

\section{Figure 2 Situating the socio-economic sphere in the Earth system}

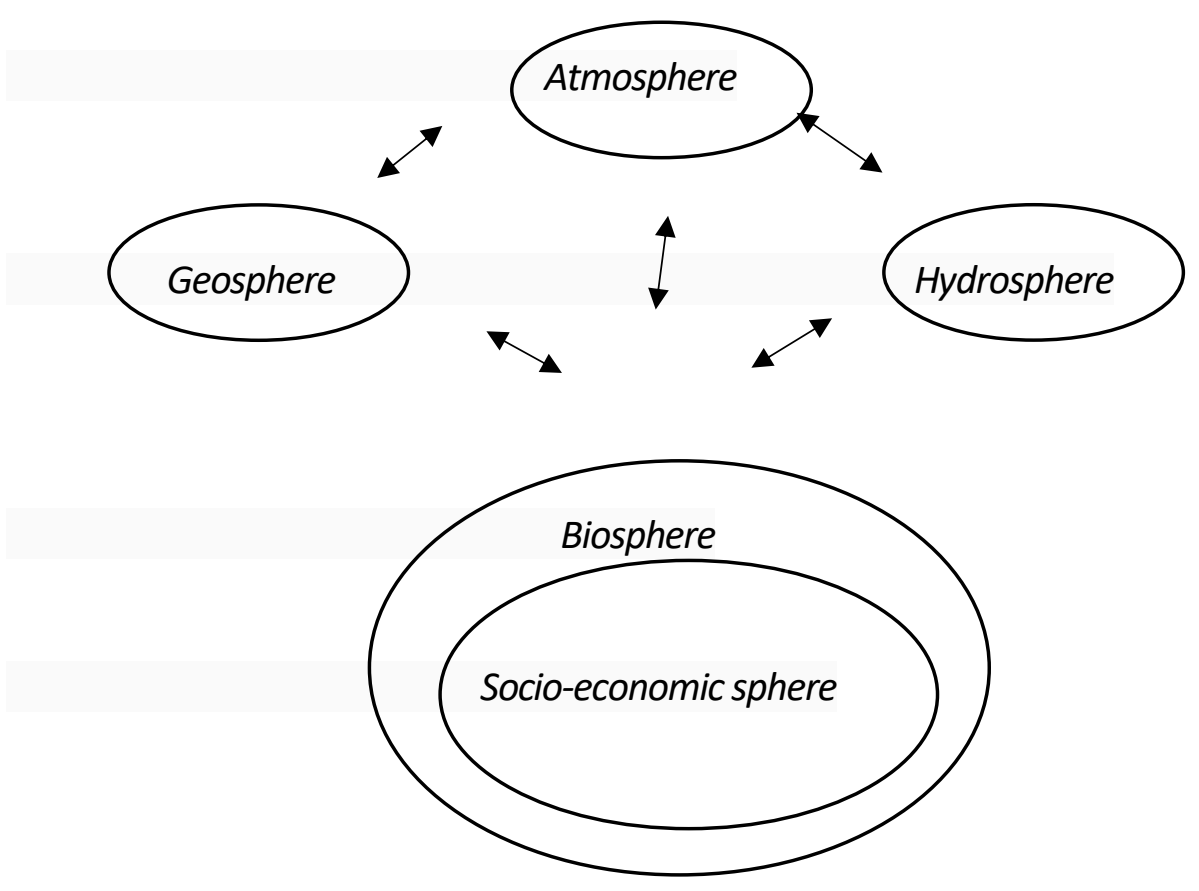

Source: Lagoarde-Segot \& Martinez (2020)

\subsection{Economic diversity}

In order to study economics as a science of the social provisioning process, it is necessary to recognize the diversity of organizations and modes of economic coordination. Indeed,economic and social reality is constructed, deconstructed and reconstructed differently according to time and place. A very large number of activities (market or non-market, paying or non-paying) and organizations of very different sizes and governance participate in this process. The functioning of the economy is therefore based on the social norms, rules, culture and law specific to a time and a place.

The link between the principles of realism and diversity can be seen clearly in Figure 3 , which decomposes modern economies into three complementary systems:

- A "first system" includes capitalist organizations whose activity consists in producing and exchanging goods and services on the markets in order to make a monetary profit;

\footnotetext{
${ }^{8}$ Related definitions have been proposed by different authors, such as "the study of the processes that provide the flows of goods and services required by society to support those who participate in its activities" (Gruchy, 1987). Another definition refers to "the study of how societies organize themselves to reproduce human life and enhance its quality" (Nelson, 2009). Studying economics also involves analyzing the "social laws that govern the production and distribution of the means of existence of human beings organized in social groups" (Aglietta, 1979/2015).
} 
- A "second system" is made up of state organizations whose activities provide public goods (education, health, infrastructure, etc.).

- A "third system" includes non-capitalist market organizations based on a principle of "reciprocity" and "common good".

The principles of diversity and realism have led the authors of the textbook to establish, throughout the text, connections with other disciplines (notably the social sciences and the earth sciences).

\section{Figure 3: The three economic systems}

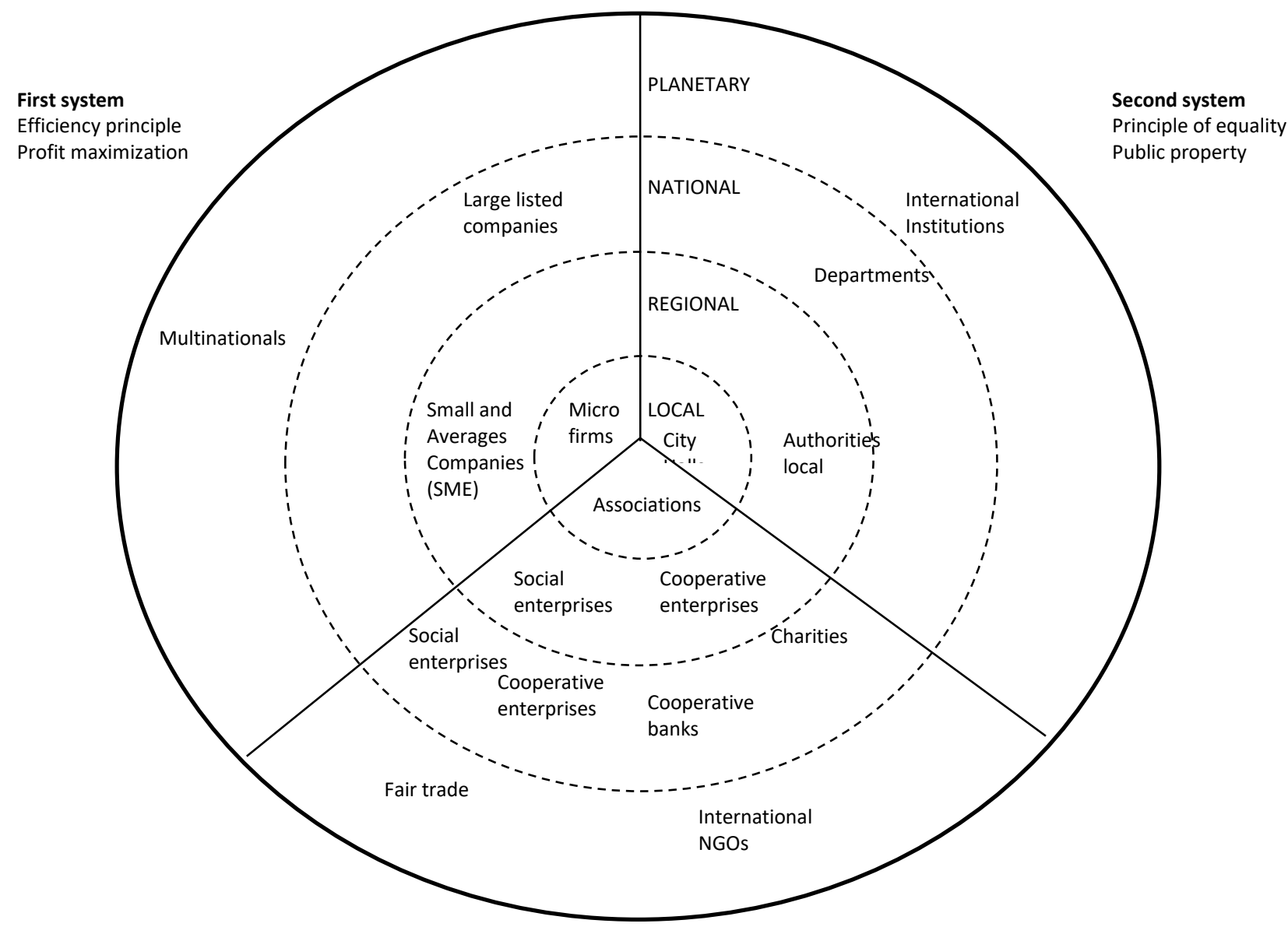

Source: Pearce (2003)

$$
\begin{aligned}
& \text { Third sector } \\
& \text { Principle of reciprocity } \\
& \text { Societal objectives }
\end{aligned}
$$

\subsection{Pluralism}

The corollary of economic diversity is a diversity of views on how the economy works. Since economics is a social science, in which the observer is never totally separated from his object of study, economists project values, a vision of the world and interests in their analyses. The history of economics is, moreover, riddled with controversies between schools of thought that continue to this day (see Figure 4). Orthodox economics includes a core school (neoclassical economics) and several schools such as 
the neo-Keynesian school, game theory and several approaches based on imperfect competition and information asymmetries. Some fields of study (such as economic history, behavioral finance, comparative economics, and experimental microeconomics) borrow from orthodox approaches as well as from other disciplines, or from heterodox schools. Finally, the heterodox schools include communities of various sizes and audiences, such as post-Keynesian economics, ecological economics, feminist economics, economic geography, socioeconomics, critical management studies, evolutionary economics, Austrian economics, Marxian economics and critical realism. The main points of disagreement between the orthodox and heterodox schools on key topics (epistemology, methodological rationality, economic core, political core) are summarized in Table 2.

Table2Presuppositions of orthodox and heterodox schools of economics

\begin{tabular}{|l|l|l|}
\hline Presupposition & Heterodox schools & Orthodox schools \\
\hline Epistemology/ontology & Realism & Instrumentalism \\
\hline Rationality & $\begin{array}{l}\text { Environment-consistent } \\
\text { rationality, satisficing } \\
\text { agent }\end{array}$ & $\begin{array}{l}\text { Hyper model-consistent } \\
\text { rationality, optimizing } \\
\text { agent }\end{array}$ \\
\hline Method & Holism, organicism & Individualism, atomicism \\
\hline Economic core & $\begin{array}{l}\text { Production, growth, } \\
\text { abundance }\end{array}$ & $\begin{array}{l}\text { Exchange, allocation, } \\
\text { scarcity }\end{array}$ \\
\hline Political core & Regulated markets & Unfettered markets \\
\hline
\end{tabular}

Source: Lavoie (2015), p.12. 


\section{Figure 4: The different approaches in economics}

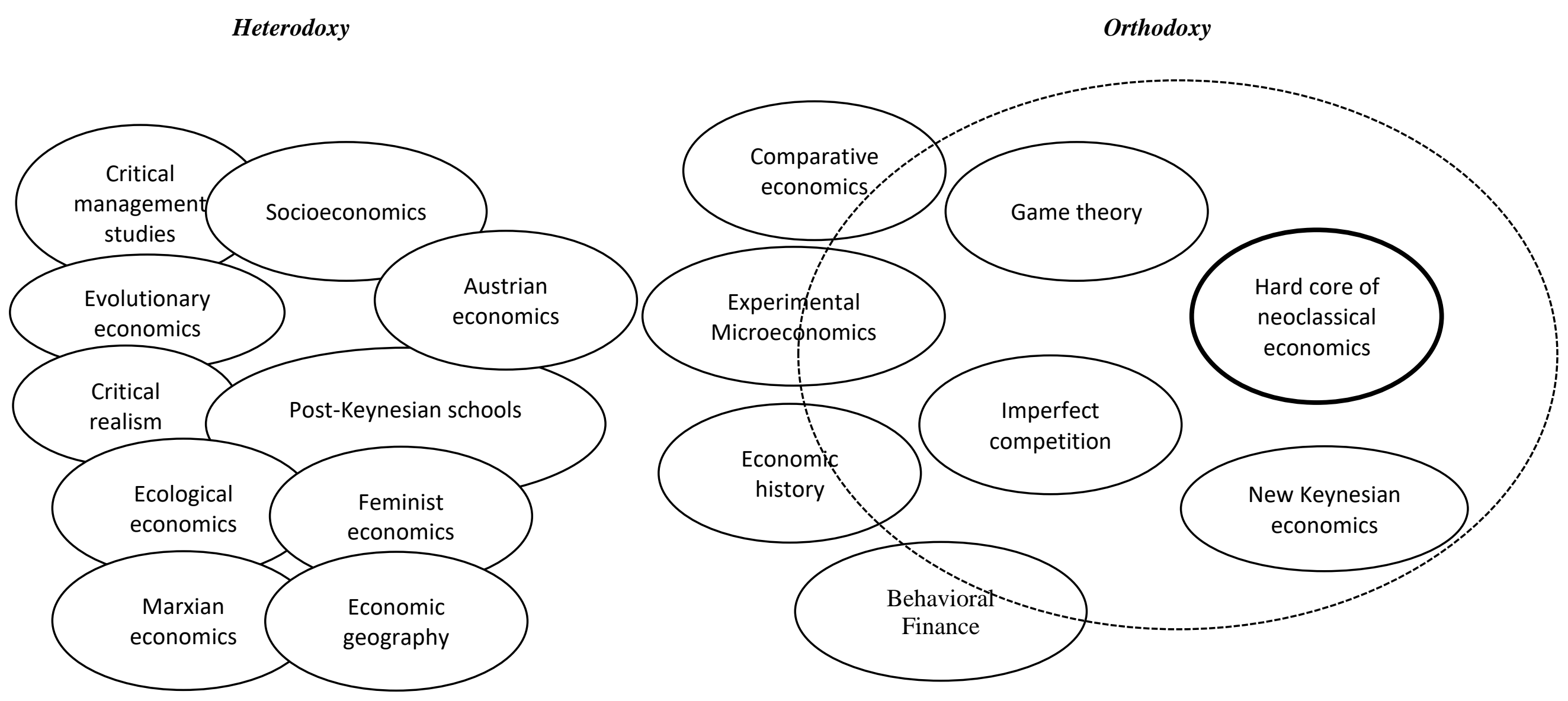

Source: adapted from Labrousse (2019), Dobusch and Kapeller (2002) 
People tend to adopt new ideas only if they are consistent with what they already think (confirmation bias) (Nickerson, 1998). Regardless of the discipline, pluralistic teaching therefore allows students to better understand complexity (Aerni et al., 1999: 29), and to strengthen their cognitive skills for solving new problems (Dorman, 2002: 490). In particular, a pluralistic economics education could equip new generations to respond to the unpredictable socioeconomic effects of the Anthropocene.

Pluralism in economics means recognizing the legitimacy of different schools of thought. Of course, pluralism is opposed to monism, in which only one approach to economics is taught. In the context of this textbook, pluralism, however, does not consist in establishing a "catalog" of alternative theories, all put on the same level, or in simply enriching an orthodox approach by opening up to other approaches. It is about making available to students, for each topic covered, the most relevant approaches from the perspective of the SDGs, describing transparently the assumptions on which these approaches are based, and above all, leading students to use various theories to articulate informed reasoning on economic, social and ecological perspectives in the 21 st century.

Yet, despite the great diversity of economic thought; the teaching of economics at the university level is marked by the hegemony of orthodox economics. For example, in France, only $10 \%$ of the professors recruited at the university level since 2000 subscribe to a heterodox approach (Labrousse, 2017). Moreover, the ten years since the 2008 crisis have not corrected the monistic drift in economics and finance teaching. A survey of 198 French teacher-researchers revealed that only $25 \%$ of them considered that the financial crisis had significantly changed their teaching; and $75 \%$ of them still considered it a priority to teach the theory of the efficiency of financial markets (Couppey-Soubeyran et.al, 2018) ${ }^{9}$.

\subsection{Social justice}

The idea of a science without value judgments was challenged as early as 1927 with the discovery by Heisenberg of the uncertainty principle. When we try to measure an electron (one of the components of an atom), we can observe either its position (which implies that an electron is a particle) or its motion (which implies that an electron is a wave), but never both. To the question: is an electron a wave or a particle? Heisenberg answers: it depends. The definition of what an electron is therefore depends on how we choose to observe it.

This discovery turned the conception of science on its head by demonstrating that all scientific activity necessarily rests on value judgments. A robust scientific approach is not value laden, but recognizes and makes explicit underlying judgments.

The question of the values underlying the analyses is rarely addressed in economics textbooks. This can perhaps be explained by the influence of a particular conception of philosophy of science in economics in economics: logical positivism. Developed by participants in the Vienna Circle in the 1920s, and imported into economics by Lionel Robbins (1898-1984), this school of thought resolutely separates the domain of "facts" from that of "values". Facts" are tangible, measurable and verifiable. Values, which belong to the realm of metaphysics, are invisible, and must therefore be set aside.

This dichotomy was challenged, among others, by Hilary Putnam: "facts" and "values" are not in fact distinct, but rather inextricably entangled. Indeed, each term in a statement that aims to describe a "fact" always implicitly rests on a set of beliefs and knowledge, which are based on a worldview and, ultimately, on values. For example, emphasizing the "cruelty" of a man who beats a child is both a description of a fact and an ethical judgment: the use of the term "cruelty" describes both the use of violence by an individual in a position of strength on another individual in a position of weakness, and

\footnotetext{
9 This problem may explain the relative decline of the economics stream in French higher education. The "economics" stream accounts for only $7 \%$ of the French student body that follows a course of study in which economics is a component (Hautcoeur, 2013).
} 
condemns this action. In economics, stressing the "Pareto-efficiency" of an income distribution is simultaneously an objective description of a particular state of the economy, and an ethical judgment: in fact, using this concept dispenses with the need to question the causes of income distribution, or its macroeconomic and social consequences. In economics, as in other sciences, value judgments are expressed mainly through language and the concepts used.

The first step of a true scientific approach in economics is therefore to recognize and explain how our subjective choices can influence our judgments. It would therefore be wrong - and intellectually dishonest - to claim that economic knowledge is always perfectly objective. Among all the values that may animate economists, the authors of the textbook share an explicit concern for the search for social justice. As the "Nobel" prize-winning economist Amartya Sen (1970) points out ${ }^{10}$ :

"An economy in which some people are bathed in luxury and others are almost starving remains optimal (in the neoclassical sense); as long as it is impossible to improve the situation of the starving without reducing the pleasures of the rich. A society or an economy can therefore be "Pareto-optimal" and perfectly disgusting.

Amartya Sen, Collective Choice and Social Welfare, 1970

\subsection{An experiential theory of learning in economics}

Training new generations to meet the challenges of the Anthropocene is an ambitious learning goal. It therefore requires the use of an effective learning theory. In his book Experience and Education (1938), Dewey asserted that knowledge cannot be transmitted vertically, but socially from lived experiences:

"The principle that development of experience comes about through interaction means that education is essentially a social process" (Dewey, 1938, p.58)

Whatever the subject taught, the method proposed by Dewey consists in placing the learner in a "concrete situation" allowing him to appropriate the pedagogical content. The core of this learning process is experience, that is, an activity that mobilizes a set of means to achieve an explicit educational objective. Adopting experiential learning in economics implies breaking with the traditional process of knowledge acquisition, transmitted vertically by the teacher. The teacher must now design and implement learning experiences based on interaction, while learners become actors of their learning. During each experiment, learners should be given time to reflect on their newly accumulated knowledge. Experiential learning pays particular attention to the choice of educational activities, which must be able to generate interest and meaning for the learner. Indeed, it is the intensity of the impulse or desire felt by the learner that will determine the extent of his or her effort, and therefore his or her performance. If these conditions are met, a virtuous circle is set up in which the students' commitment and knowledge increase and are self-reinforcing. From a cognitive point of view, the interest of this process is that students not only gain abstract knowledge, but also the ability to apply it in problem-solving situations. The textbook also assumes that controversy-based experiential learning is particularly appropriate for pluralistic economics education. The textbook (and the additional resources it provides) hence allows

\footnotetext{
${ }^{10}$ The concern for social justice can be traced back to the work of Adam Smith (1776):

"Servants, workers and artisans of all kinds make up the largest part of any political society. Now, can one ever consider as a disadvantage for the whole that which improves the lot of the greater part? Certainly, one should not consider as happy and prosperous a society whose most numerous members are reduced to poverty and misery. Fairness alone, moreover, requires that those who feed, clothe and house the whole body of the nation, should have, in the product of their own labor, a sufficient share to be themselves fairly fed, clothed and housed. »
}

An Inquiry into the Nature and Causes of the Wealth of Nations (1776), Adam Smith (trans. Germain Garnier), ed. Otto Zeller, 1966, chap. 8, book 1, p. 108. 
the teacher to design experiences that allow students to construct views and debate them in a constructive and respectful setting (Aerni et al, 1991; Peterson and McGoldrich, 2009). These social interactions then serve to reinforce the learning and cognitive process, and expose students to the diversity of views of their peers. Experiential and pluralistic learning in economics should thus achieve the following goals:

1. develop skills of synthesis, analysis and written and oral expression;

2. understand the complexity of interacting socio-economic and ecological mechanisms;

3. offset the effects of hyper-specialization in higher education on the cognitive domain;

4. connect economic issues to other social sciences;

5. be able to understand the ins and outs of contemporary economic debates, especially concerning the Agenda 2030;

6. apply economic knowledge to understand "real" life (of individuals and businesses)

7. make students want to study and continue learning throughout their professional and civic lives.

\section{Case study: the pilot course at KEDGE BS}

KEDGE BS is a French "Grande Ecole" (business school) with triple accreditation in higher education and offering undergraduate and postgraduate programs, mainly on the Marseille, Bordeaux and Paris campuses.

The textbook and its pedagogical approach have been tested in a pilot course - the fundamental economics course of the first year of the "Grande Ecole" program at KEDGE Business School (Bsc). This is a compulsory course, followed annually by about 1,000 students simultaneously on the Bordeaux and Marseille campuses. The course is structured over 9 weeks, with a theme covered each week, and allows students to validate 100 ECTS credits. The background of the students is quite varied. Some have entered KEDGE BS after a first university degree (admission by "voie parallèle"); however, the majority are recruited from the prestigious "classes préparatoires" (prep class in economics or science). Some students have already studied economics in their prep class, while others, who come from scientific streams, or have been admitted via a parallel path, are discovering economics with this course.

With the support of the Associate Dean for Pedagogy, the Economics course syllabus (which used to rely on "orthodox" approaches) was completely revised in the summer of 2019. In September 2019, the new syllabus was evaluated and received a label from "SDSN France". This new course was then offered two years in a row in 2019-2020 and 2020-2021 by a team of five professors (three in Bordeaux, two in Marseille), each responsible for several sections of about 70 students. Today, about 2,000 students have taken this course.

The first session of the course (2019-2020) allowed us to test and develop the new content in a traditional teaching setting. From the second session onwards (2020-2021), we were able to put into practice an experiential pedagogy. Given the number of participating students, we relied heavily on digital tools. This approach allowed us to effectively keep students engaged during the lockdown period, and then to adapt more easily to changing sanitary constraints (indeed, during the first semester of 2020, each section of 70 students was divided into two subgroups that took turns to follow the course in face-toface and distance learning).

\subsection{The social framework}

Experiential learning requires the creation of interconnected learning communities, accessible by students both inside and outside the classroom (Bloom, 1956; Perry, 1970). Each community of four students has access to a variety of resources: textbook chapters, academic articles relevant to the topic, news articles, links to databases, videos or podcasts, and can also upload their own resources. Students 
also have access to several communication tools integrated into the digital platform (chat, videoconference, email, faq forum...).

The implementation of learning communities has three main objectives. First, these communities provide an informal setting to discuss the relevance of different economic approaches in the contemporary world, allowing students to connect the economics course to their lived experiences (Emami and Davis 2009; Peterson 2011; Peterson and McGoldrick 2009). Second, learning communities facilitate collaborative learning, allowing students to share ideas, resources, and to cooperate to solve problems (Dorman (2002)). Third, learning communities make it possible to incorporate pluralism into the working methods. For example, the teacher can ask the communities to construct proposals based on the contributions of all the members (Aerni et al, 1999). These informal exchanges are enhanced by a ritual discussion-debate at the beginning of each session, around an economic problem related to the 2030 Agenda, in a benevolent and pluralistic atmosphere.

\subsection{Steps in designing an experiential course in pluralistic economics}

For the teacher's point of view, traditional academic pedagogy typically requires first working with course materials (e.g., a powerpoint presentation), then developing instructional activities around these materials, and finally identifying corresponding learning objectives. Experiential pedagogy involves reversing this process, by first identifying learning objectives, then designing the learning experiences, and finally developing the corresponding support materials (Wiggins and McTighe, 2005: 17-19).

The learning objectives cover the knowledge, facts, concepts, principles and skills developed in the course. In the context of our economics course, these objectives are the following:

- Understanding and memorizing economic information, concepts and tools (Fink, 2003: 31).

- Learning the learning process to become autonomous "learners" (Fink, 2003: 50-55)

- Using basic knowledge, developing new skills, developing thinking skills (critical, creative and practical) and dealing with complex economic problems related to the Agenda 2030 (Fink, 2003: 38);

- Connectinf economic knowledge, personal ideas and real-life experiences (Fink, 2003: 31).

- Developing new feelings, interests and values - that is, making sense of what is being learned (Fink, 2003: 74)

For each of the themes studied, the learning objectives are achieved by mobilizing the three learning categories proposed by Bowen (2005):

- Active learning, in which the student's involvement is sought in the learning process itself. This means that learning goes beyond the mere understanding of content and also concerns skills;

- Experiential learning, in which student engagement is sought in the subject matter of the course content. For example, studying current issues by exchanging experiences and views among learners increases learners' interest in the subject and content of the course;

- A multidisciplinary learning process, which allows for the re-situation of pluralist economics in the field of social sciences (often in connection with issues and topics dealt with in their other courses too), and increases student's engagement. 
Table 3 illustrates how active learning, experiential learning, and multidisciplinary learning are employed to achieve specific learning objectives.

Table 3 Types of learning used

\begin{tabular}{|c|c|c|}
\hline Learning & Features & Learning objectives \\
\hline Active learning & $\begin{array}{l}\text { Knowledge use, knowledge and } \\
\text { skill development } \\
\text { Giving meaning to knowledge }\end{array}$ & $\begin{array}{l}\text { Apply knowledge } \\
\text { Discover the social enterprises } \\
\text { and the cooperative sector } \\
\text { Understand various } \\
\text { mechanisms of causality } \\
\text { Differentiate and apply } \\
\text { economic concepts } \\
\text { Analyze dynamic effects } \\
\text { through economic modelling }\end{array}$ \\
\hline Experiential learning & $\begin{array}{l}\text { Integration of links between } \\
\text { economic knowledge, ideas and } \\
\text { lived experience } \\
\text { Giving meaning to knowledge }\end{array}$ & $\begin{array}{l}\text { Situate knowledge and think } \\
\text { critically } \\
\text { Questioning economic } \\
\text { measurement tools } \\
\text { Exploring macroeconomic } \\
\text { paradoxes } \\
\text { Analyze/compare economic } \\
\text { systems } \\
\text { Use public international } \\
\text { databases }\end{array}$ \\
\hline Multidisciplinary learning & $\begin{array}{l}\text { Comprehension } \\
\text { memorization }\end{array}$ & $\begin{array}{l}\text { Learning about diversity, } \\
\text { pluralism, sustainability and } \\
\text { justice } \\
\text { Understanding economic } \\
\text { diversity } \\
\text { Understand the contributions } \\
\text { and limitations of economic } \\
\text { models } \\
\text { Analyze policy controversies } \\
\text { around the Agenda } 2030\end{array}$ \\
\hline
\end{tabular}

These learning objectives make it possible to evaluate various skills: mastery of quantitative tools, quality of writing, and the mobilization of a pluralistic and interdisciplinary perspective in the work submitted by students.

The second step is to design the learning experiences, i.e., the pedagogical activities that monitor the learners' educational progress. The possibilities for pedagogical activities in experiential learning in economics are numerous. An important step is to identify the sequencing of topics that will maximize learner engagement in the course.

In the third step, it is necessary to look for resources related to the different themes. These resources must be multiple, diverse, and must capture the learner's attention. They must allow for the validation of previously identified and defined learning objectives, and be integrated into a rich, demanding, benevolent and error-tolerant learning environment. They are accompanied by clear instructions that allow students to quickly engage in the activities. To develop these learning experiences, we asked ourselves four questions for each theme: 
- What are the learning objectives sought? (both in terms of knowledge-facts, conceptsprinciples-, as well as skills - know-how and knowing how to be: processes, procedures, strategies)

- What would be appropriate instructional activities for experiential learning?

- What resources should be provided to learners?

- What learning materials/tools are needed?

In each experiment, we seek to create cognitive dissonance between what is known by some and what the new experiment is intended to learn. For example, we introduce the international macroeconomic equilibrium equation using excerpts from Costa-Gavras' film Adults in the Room (2019) about the eurozone crisis and the fiscal austerity imposed on Greece in the 2010s. This perspective challenges students and leads them to engage in more detail with the major paradoxes of macroeconomic analysis, and to explore them further through macroeconomic simulations (conducted in Excel or via MacSim2 (2014), a serious game software). This cognitive dissonance reinforces engagement, which leads to better attention and a stronger cognitive effort, a stronger motivation of the learner (Fastinger, 1958).

Finally, the third step is to identify the digital media and tools used in the module. This last step is important because it helps to identify a framework and to build a structured and enriched environment for the learning process. Table 4 describes the pedagogical progression proposed in this course. It details the theoretical perspectives to which the sessions refer, the learning objectives sought for each session, and the pedagogical activities chosen as part of the learning experience. 


\section{Table 4 Progression pedagogy of the KEDGE BS fundamental economics course}

\begin{tabular}{|c|c|c|c|c|}
\hline Week & $\begin{array}{l}\text { Chapter of the } \\
\text { manual }\end{array}$ & Theoretical perspectives & Learning Objectives & Educational activities \\
\hline 1 & $\begin{array}{l}\text { Economics: theory } \\
\text { and reality }\end{array}$ & $\begin{array}{l}\text { Ecological economics, critical } \\
\text { realism, Polanyian economics, } \\
\text { socioeconomics, feminist } \\
\text { economics }\end{array}$ & $\begin{array}{l}\text { - Multidisciplinary learning } \\
\text { Situating the economic sphere in relation to the Earth } \\
\text { system } \\
\text { Situating economics in the social sciences } \\
\text { - Experiential Learning; } \\
\text { Applying pluralism, sustainability and justice to } \\
\text { economic analysis } \\
\text { - Active learning: } \\
\text { Learn about the } 17 \text { United Nations Sustainable } \\
\text { Development Goals (SDGs) }\end{array}$ & $\begin{array}{l}\text { Controversy - The International Report } \\
\text { on the SDGs: Analysis and links to the } \\
\text { student experience }\end{array}$ \\
\hline 2 & $\begin{array}{l}\text { Systems and } \\
\text { economic diversity }\end{array}$ & $\begin{array}{l}\text { Polanyian economics, } \\
\text { institutional economics, socio- } \\
\text { economics, heterodox theories } \\
\text { of the firm }\end{array}$ & $\begin{array}{l}\text { - Multidisciplinary learning } \\
\text { Differentiate between capitalism, the market, the } \\
\text { firm } \\
\text { - Experiential learning } \\
\text { Question the possible economic measures of the } \\
\text { notion of "value } \\
\text { Understand economic diversity (private sector, } \\
\text { public sector, third sector) } \\
\text { - Active learning } \\
\text { Focus on social enterprises and the cooperative } \\
\text { sector }\end{array}$ & $\begin{array}{l}\text { Analyze the cooperative sector: } \\
\text { principles, enterprises. } \\
\text { Controversy over the notions of "values" } \\
\text { and "value creation" by the company. }\end{array}$ \\
\hline 3 & $\begin{array}{l}\text { Modern money and } \\
\text { payment systems }\end{array}$ & $\begin{array}{l}\text { Post Keynesian economics, } \\
\text { MMT, ecological economics, } \\
\text { economic history }\end{array}$ & $\begin{array}{l}\text { - Multidisciplinary learning } \\
\text { Applying double-entry accounting to economic } \\
\text { analysis } \\
\text { - Experiential learning } \\
\text { Exploring the paradoxes of a monetary } \\
\text { economy of production in the Anthropocene } \\
\text { - Active learning }\end{array}$ & $\begin{array}{l}\text { Differentiating complementary local } \\
\text { currencies and crypto-currencies. } \\
\text { Exploration of advantages and limits of } \\
\text { local currencies and cryptocurrencies } \\
\text { from the perspective of Agenda } 2030 . \\
\text { Simulation game. }\end{array}$ \\
\hline
\end{tabular}




\begin{tabular}{|c|c|c|c|c|}
\hline & & & $\begin{array}{l}\text { Understand the various mechanisms of money } \\
\text { creation in the real economy } \\
\text { Placing the different payment instruments in the } \\
\text { monetary pyramid }\end{array}$ & \\
\hline 4 & $\begin{array}{l}\text { Monetary } \\
\text { macroeconomics }\end{array}$ & $\begin{array}{l}\text { Post-Keynesian economics, } \\
\text { French regulation school }\end{array}$ & $\begin{array}{l}\text { - Experiential learning } \\
\text { The great paradoxes of macroeconomic analysis } \\
\text { Analyze the macroeconomic system with the } \\
\text { monetary circuit } \\
\text { - Active learning } \\
\text { Differentiate between inside and outside financial } \\
\text { wealth } \\
\text { Understanding the determinants of the Public Debt } \\
\text { Ratio }\end{array}$ & $\begin{array}{l}\text { Analyze the determinants of the public } \\
\text { debt ratio in different regulatory } \\
\text { frameworks since 1914. } \\
\text { Controversy: the COVID-19 public debt }\end{array}$ \\
\hline 5 & $\begin{array}{l}\text { Introduction to } \\
\text { economic modeling }\end{array}$ & $\begin{array}{lr}\text { Stock-flow } & \text { consistent } \\
\text { modeling; } & \text { post-Keynesian } \\
\text { economics, } & \text { ecological } \\
\text { economics } & \end{array}$ & $\begin{array}{l}\text { Multidisciplinary learning } \\
\text { Understand the contributions and limitations of } \\
\text { economic models } \\
\text { Understand the impact of the assumptions of the } \\
\text { different model categories on their conclusions } \\
\text { - Active learning } \\
\text { Master the accounting and behavioral elements of } \\
\text { stock-flow modeling } \\
\text { Analyze the dynamic effects of external money } \\
\text { creation }\end{array}$ & Simulation game \\
\hline 6 & Open economy & $\begin{array}{l}\text { Neoclassical economics, } \\
\text { dependency theory, ecological } \\
\text { economics }\end{array}$ & $\begin{array}{l}\text { - Multidisciplinary learning } \\
\text { Analyze the controversies around international trade } \\
\text { from the perspective of the SDGs } \\
\text { - Active learning } \\
\text { Learn to read a balance of payments and understand } \\
\text { the limitations of the information provided } \\
\text { Calculate and interpret the macroeconomic } \\
\text { equilibrium of a country } \\
\text { - Experiential learning } \\
\text { Use public international databases }\end{array}$ & $\begin{array}{l}\text { Analyze the carbon impact of the trade } \\
\text { balance of a country of your choice }\end{array}$ \\
\hline
\end{tabular}




\begin{tabular}{|c|c|c|c|c|}
\hline 7 & $\begin{array}{l}\text { International Trade } \\
\text { and Finance }\end{array}$ & $\begin{array}{l}\text { National accounting, economic } \\
\text { and financial history, } \\
\text { geopolitics }\end{array}$ & $\begin{array}{l}\text { - Active learning } \\
\text { Calculate the mirror image of a country's balance of } \\
\text { payments } \\
\text { Experiential learning } \\
\text { Observe the link between trade and financial } \\
\text { imbalances between countries } \\
\text { - Multidisciplinary learning } \\
\text { Understand the evolution of the international } \\
\text { financial architecture since } 1914 \text {. } \\
\text { Situate the achievements in the context of the } \\
\text { debates around the euro zone }\end{array}$ & $\begin{array}{l}\text { Develop the balance of payment's } \\
\text { "mirror image" of a country of your } \\
\text { choice and analyze your findings using } \\
\text { economic, historical and geopolitical } \\
\text { information. }\end{array}$ \\
\hline
\end{tabular} \\ doi:10.20944/preprints202103.0769.v1}




\subsection{The learning process}

We have designed the pedagogical process in three phases: before the class, during the class, and after the class. The objective is to allow time for learners to engage individually with the material provided, to cooperate with others on learning experiences, and to reflect on what has been learned during the process.

\subsubsection{Before the class}

Before each class session, community members were asked to read individually the corresponding textbook chapters and to consult the additional resources provided (podcasts, videos, news articles...). These additional resources are recent and diverse, and were carefully selected to stimulate and channel students' attention. This first phase aims to stimulate learners' attention, which is cognitive a mechanism for filtering, selecting and processing information.

During this preparatory phase, learners are asked to (i) write an individual summary of their readings and then (ii) debate among themselves to write a response to a reflection question proposed by the teacher and linked to the 2030 Agenda. The themes covered include, for example, the problem of managing the world's natural resources (water, forests, oceans, etc.), always presented in the form of a controversy. For example, are the world's natural resources factors of production, public goods or common goods?

This first experience allows students to engage in the content, by confronting points of view with other people in the group, and thus to go beyond the stage of "simply" understanding the course. It is therefore a "controversy-based pedagogy", which requires students to take a position and to put forward arguments to defend their points of view. For each topic treated, each student is thus led to follow three cognitive stages:

1. Understanding: Understanding and knowing the different paradigms that underlie the controversy;

2. Diagnosis: make a diagnosis of the complexity and context of the controversy;

3. Judgment: articulating an informed and personal argument in response to a controversy

\subsubsection{During the class}

The three-hour class session with the teacher is divided into two parts. The first part consists of an informal debate between the groups on the topics covered, followed by a formal debate "opposing" several groups selected by the teacher. Students watching the debate can react live via a chat and vote for the "winning" team of the debate.

Regardless of the controversy (such as, for instance, the responsibility of capitalism in the global ecological crisis), the goal is not to discover "the truth," but to have students generate an effective rhetoric consistent with the economic approach being advocated. This rhetorical function is all the more important since economic research is often the basis for the development of public policies (Freeman, 2009). The criteria for evaluating the arguments defended by students include their understanding of the link between the hypotheses, the scientific content of the theories, and their application to the question posed (Denis, 2009).

Controversy-based pedagogy is an effective pedagogical strategy in the context of a pluralistic economics course. It allows for interaction and dialogue between different economic theories in the classroom. Students are thus able to synthesize, transform, polarize, and clarify differences in 
viewpoints, without necessarily aiming for a uniform frame of reference. Controversy also empowers students by allowing them to construct their own worldview. Controversy-based pedagogy also allows for the individual moral and ethical development of students, who develop open-mindedness and tolerance by exploring "their own values and those of others" (Barone, 1991: 18). For each topic discussed in class, students therefore learn about existing theoretical alternatives, and question the relevance of the assumptions of these theories, and their implications in the real world, in an exercise of benevolent confrontation of points of view. Thus, students are able to:

- Respect the legitimacy of alternative approaches and understand them;

- Justify the choice of a theoretical approach over other approaches;

- Evolve their speech as events unfold and as a result of the debates;

- Welcome ideas from other approaches (even if these ideas challenge their own ideas)

In the second part of the course, the teacher guides the groups of students through an activity (case study, simulation) generally based on quantitative tools. This case study allows them to consolidate their knowledge acquired during the discussion phase. The knowledge is then "internalized" allowing the learners to be available to acquire new knowledge.

During this process, the teacher is no longer the "knower" but becomes the leader: he/she must listen to the learners and lead them towards the learning objective, while leaving them the initiative in carrying out the pedagogical activities.

During this phase with the teacher, there are exchanges between learners, and between learners and teacher as well. It is during these exchanges that learners can progress in their learning, by making mistakes and correcting them before handing in their work. In other words, mistakes are also an experience (as long as they are not overly sanctioned). Indeed, the stress of punishment constitutes a learning inhibitor (Dehaene, 2012). Thus, during the class session, students are allowed to make mistakes. The teacher's mission is to identify the students' mistakes and guide them to correct them. Thus, exchanges and feedback are essential, the validation of ideas and results the learning community and by the whole class allows a social reinforcement of the construction of knowledge.

\subsubsection{After the class}

After the course, each student can check his or her knowledge by taking an individual quiz to validate a dedicated module of the Sustainability Literacy Test. Then, exchanges between students and with the teacher continue on social networks, via forums. This last step allows students to consolidate what they have learned, to "internalize" the knowledge, to make it "automatic".

Here are some of the qualitative comments obtained:

"Having done a CPGE (prep class), I was already familiar with almost all the content of the economics courses. This allowed me to brush up on a few things and deepen my knowledge. »

"I enjoyed this course because it was quite interactive with a lot of conversation around the course previously studied....

"A structured course with an original reversed pedagogy, which allows to learn differently. On the other hand, I found the case studies in the course difficult to carry out....

"1. very interesting, interactive and topical course. The organization of the course is very good: half theory (lectures), half practice (exercises). ...2. A little too much work" 
"The structure of the course is very relevant, very much in line with current events, making the course much more understandable. The fact that the course was built using the SDGs is also important because our generation needs to be aware of the impacts of the SDGs. Also, this economics course went far beyond just giving us information about the laws of this discipline or the major economic rules, as it even pushed us to develop a relevant way of thinking and taking a step back that I am sure will serve us well in the future..... »

"I really appreciated this course, very interesting in its approach to economics. The principle of synthesizing a course is very good for regular work, especially in a distance learning context where I didn't really get hooked on most of the courses. The group work is also interesting... "

\section{Conclusion}

The 2030 Agenda calls for a rethinking of education and training of new generations. In France at least, economic and financial education at the university level is still marked by monism, by an insufficient consideration of the relationship between the economy, society and the natural world, and by the neglect of learning theories. It is therefore necessary, from the perspective of the objectives of sustainable development, to reconsider both the content and the pedagogy of economics education.

In this article, we have presented an initiative led by members of the PoCfiN network (SDSN France) in response to these challenges: the writing of the manual "Ecological Money and Finance" textbook written by members of the PoCfiN Alliance (SDSN France). This initiative takes note of the performativity of economics and intends to use it as a vector to renew the thinking of tomorrow's leaders. This textbook, to be published in 2022, will make it possible to teach economics and finance based on four principles: realism, pluralism, diversity and justice. To effectively achieve these long-term learning objectives, this textbook also proposes to apply experiential learning theory to the study of economics. In this article, we have therefore detailed the objectives, the hypotheses, and the contents proposed in this new textbook. Then, we have described the principles of an experiential pedagogy of economics, and indicated how this textbook can be used as a tool, taking as a case study the fundamental economics course of the Grande Ecole program at KEDGE BS.

Of course, the pedagogical approach presented here is evolutive. For example, in the future, we are considering a new learning experience that directly involves learners in the design of the learning activities and in the evaluation of their performance (using "reverse pedagogy"). Another experiential learning project is being considered: a cooperative project, in which all learners will have to participate in the creation of a new ecological, complementary local currency. In all cases it is responsibility of each teacher to adapt the content and teaching experiences proposed to the audience and to the specificities of the teaching program in which he/she intervenes 


\section{References}

Aerni, A.L., Bartlett, R., Lewis, M., McGoldrick, K. and Shackelford, J. (1999) 'Towards a Feminist Pedagogy in Economics' Feminist Economics, vol. 5(1), pp. 29-44.

Banks, N., Schneider, G. and Susman, P. (2005) 'Paying the Bills is Not Just Theory: Service Learning about a Living Wage' Review of Radical Political Economics, vol. 37(3), pp. 346-356.

Barkley, E.F., Cross, K.P. and Major, C.H. (2005) Collaborative Learning Techniques: A Handbook for College Faculty. San Francisco, CA: Jossey-Bass.

Barone, C.A. (1991) 'Contending Perspectives: Curricular Reform in Economics' Journal of Economic Education, vol. 22(1), pp. 15-26.

Bloom B.S. (ed.) (1956) Taxonomy of Educational Objectives, the classification of educational goals - Handbook I: Cognitive domain. New York: McKay.

Borg, J.R. and Borg, M.P (2001) "Teaching Critical Thinking in Interdisciplinary Economics Courses" College Teaching, vol. 49(1), pp. 20-29.

Bowen, S. (2005) "Engaged Learning: Are We All on the Same Page.

Buiter, W. (2009) 'The unfortunate uselessness of most "state of the art" academic monetary economics', Financial Times, 3 March 2009.

Dehaene, S. (2012) What does neuroscience tell us about best pedagogical practices? Crossed Perspectives on Economics, 2(2), 231-244.

Demeulemeester J.L. (2019) Reflections on the teaching of economics Revue Nouvelle, $\mathrm{n}^{\circ} 7$ / July 2019, pp. 4656.

Denis A. (2009) IREE " Pluralism in Economics". International Review of Economic Education. Vol 8, Issue 2, 2009. Pp :6-22.

Dorman, P. (2002) 'Pedagogy and Political Economy' Review of Radical Political Economics, vol. 24, pp. 487492Janice Peterson (2013) Economic education after the crisis: Pluralism, History, and Institutions Journal of Economic Issues Vol 17, No 2, June

Dron, D., 2015. Pour une régulation écosystémique de la finance. Veblen Institute https://www.vebleninstitute.org/IMG/pdf/pour_une_regulation_ecosystemique.pdf Accessed date: 9 May 2019.

Fink, D. (2009) "Preface", New Directions for Teaching and Learning, volume 20, no. 119, pp. 1-7.

Fink, D. L. (2003) Creating Significant Learning Experiences: An Integrated Approach to Designing College Courses, San Francisco, CA: Jossey-Bass.

Fisher L., Hasell J., Chris- topher Proctor J., Uwakwe D., Ward-Perkins Z. and Watson C. (2018), Rethinking Economics. An Introduction to Pluralist Eco-nomics, Abingdon, Routledge.

Ford, E.J. and Leclerc, D.C. (2000) "A Constructivist Approach to College-Level Economic Education" Review

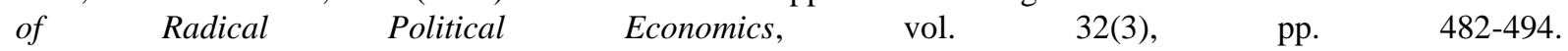
Ford, E.J, Leclerc, D.C. and Ford, D.J. (2007) "A Constructivist Approach to Learning Unemployment" Review of Radical Political Economics, $\quad$ vol. $\quad 39(3), \quad$ pp. $\quad 329-334$. Freeman, A. (2009) The Economists of Tomorrow: the Case for a Pluralist Subject 23 Benchmark Statement for Economics. International Review of Economic Education. Vol 8, Issue 2, 2009. Pp : 23-40

Galaz, V. et al. Tax havens and global environmental degradation. Nat. Ecol. Evol. 2, 1352-1357 (2018).

International Geosphere-Biosphere Programme. Global Change and the Earth System: a Planet under Pressure.

IGBP Science 4.

Hall, C.A., 2017. Energy Return on Investment. A Unifying Principle for Biology, Economics and Sustainability. Lecture Notes in Energy 36, Springer, Switzerland.

Labrousse A. (2017), "Le pluralisme, source de rigueur et de découvertes scientifiques", in Coriat et al. (2017), Misère du scientisme. À propos de l'affaire Cahuc et Zylberberg, Paris, Croquant, pp. 41-55.

Maier, M. (2008) "Pedagogy in the Pluralist Classroom" (working paper). Maier, M., McGoldrick, K and Simkins, S. (2010) "Implementing Cooperative Learning in Introductory Economics Courses", in B. Millis (ed) Cooperative Learning in Higher Education, Sterling, VA: Stylus Press.

McGoldrick, K. (1998) 'Service-Learning in Economics: A Detailed Application' Journal of Economic Education, vol. 29(4), pp. 365-376.Nickerson, R., 1998. Confirmation Bias: A Ubiquitous Phenomenon in Many Guises. Volume: 2 issue: 2,page(s): 175-220 https://doi.org/10.1037/1089-2680.2.2.175

Nyström, J.-B. Jouffray, A. V. Norström, B. Crona, P. Søgaard-Jørgensen, S. R. Carpenter, Ö. Bodin, V. Galaz, C. Folke. 2019. Anatomy and resilience of the global production ecosystem. Nature, Volume 575, DOI: 10.1038/s41586-019-1712-3

Peterson J. and McGoldrick K.M. (2009): Pluralism and Economic Education: a Learning Theory Approach. International Review of Economic Education. Vol 8, Issue 2, 2009. Pp : $72-90$

Reardon, J., Madi, M.A., Cato, M.S., 2018. Introducing a new economics. Pluralist, Sustainable and Progressive. Pluto Press, Northampton, UK. 
Sandel M. J. (2013), "Market Reasoning as Moral Reasoning: Why Economists Should Re-en- gage with Political Philosophy," Journal of Economic Perspectives, 27(4), pp. 121-140.

Screpanti (1997) Afterword". In A. Salanti, E. Screpanti (eds) Pluralism in Economics. Chelten ham: Edward Elgar, 298-307.

Svartzman, R., Dron, D., Espagne, E., 2019. From ecological macroeconomics to a theory of endogenous money for a finite planet. Ecological Economics 162 (2019) 108-120 